\title{
Anatomical and Ultrastructural Sex Differences in Mean Diameter and Thickness of Myelinated Axons in Adult Rat Corpus Callosum
}

\author{
Diferencias Sexuales Anatómicas y Ultraestructurales del Diámetro Medio y \\ Grosor de los Axones Mielinizados en el Cuerpo Calloso de Ratas Adultas
}

\author{
Amjad Shatarat ${ }^{1}$; Loai Alzghoul²; Duaa Al Qattan³ \& Maha ELBeltagy ${ }^{1,4}$
}

SHATARAT, A.; ALZGHOUL, L.; AL QATTAN, D. \& ELBELTAGY, M. Anatomical and ultrastructural sex differences in mean diameter and thickness of myelinated axons in adult rat corpus callosum. Int. J. Morphol., 38(2):505-512, 2020.

SUMMARY: Sexual dimorphism exists at all levels of the nervous system. These sex differences could underlie genderrelated differences in behavior and neuropsychological function, as well as the gender differences in the prevalence of various mental disorders such as autism, attention deficit disorders, and schizophrenia. Myelination, on the other hand, is a unique cellular process that can have a dramatic impact on the structure and physiology of an axon and its surrounding tissue. The corpus callosum (CC) is the largest of the brain commissures, which connects the cerebral cortices of the two hemispheres, and provides interhemispheric connectivity for information transfer and processing between cortical regions. Variation in the axonal properties of $\mathrm{CC}$ will alter the interhemispheric connectivity. The CC consists of myelinated and unmyelinated axons, glial cells and blood vessels. Several functional studies have reported that the function of $\mathrm{CC}$ is associated with its axons density and myelination properties. The sexual dimorphism in the axonal content of the CC has always been controversial; hence, the aim of this study was to analyze the differences in axons' diameter and myelin sheath thickness of the CC between male and female rats. For this purpose, five pairs of adult male and female rats were perfused and the $\mathrm{CC}$ were removed and sectioned. Four sections from different subregions of the corpus callosum that represent the genu, anterior body, posterior body, and splenium of the $\mathrm{CC}$ were stained and electron microscopic images were captured using stereological guidelines. Later, the axons diameter and myelin sheath thickness for each subregion were calculated and compared between males and females. Our preliminary findings of the present study indicated region specific differences in the myelinated axon thickness and diameter in the $\mathrm{CC}$ between male and female rats.

KEY WORDS: Dimorphism; Corpus callosum (CC); Electron microscope; Myelinated axons; Diameter and myelin sheath thickness.

\section{INTRODUCTION}

Neuroanatomical variability between male and female has been the target of considerable investigations. Gender studies have proven that sex influences many areas of the brain, such as the hippocampus, amygdale and neocortex (Cahill et al., 2004; Cahill, 2006; Koss \& Frick, 2017). These variations may appear in cortical thickness, volume (Diamond et al., 1981; Stewart \& Kolb, 1988; Reid \& Juraska, 1992; Mack et al., 1995), and dendritic branching in prefrontal cortex (Kolb \& Stewart, 1991; Mack et al., 1995) .
The corpus callosum (CC) is the largest of the brain commissures; it consists of about 200 million axons that interconnect the two hemispheres. Its primary function is to integrate motor, sensory, and cognitive performances between the cerebral cortex on one side of the brain to the same region on the other side.

Based on the topographical organization of $\mathrm{CC}$ cortical axons, it is evident that $\mathrm{CC}$ is usually subdivided from rostral to caudal, into the rostrum which contains fibers

\footnotetext{
${ }^{1}$ Amman-Jordan, The University of Jordan, Department of Anatomy, Jordan.

${ }^{2}$ Amman-Jordan, The University of Jordan, Department of Physiology, Jordan.

${ }^{3}$ Amman-Jordan, The University of Jordan, Department of Pathology, Jordan.

${ }^{4}$ University Menoufya, Menoufya, Egypt.

This project were funded by the University of Jordan, The Deanship of Academic research, grant no.14/2015/2128
} 
from front-to-basal area; genu that connects the prefrontal cortex and the anterior cingulated area; the anterior and posterior regions which connect the precentral cortex and the insula; and lastly the splenium connecting the parietal and occipital cortices (Witelson, 1989; Griffiths et al., 2009; Raybaud, 2010).

The importance of the corpus callosum is embedded in its considerable role in learning (Kendall, 1983) and behavior (Sigmundsson et al., 1999). Moreover, its size may vary in many disorders such as autism (Courchesne et al., 1993; Egaas et al., 1995), schizophrenia (Rossi et al., 1989), attention deficit hyperactivity disorders (Hynd et al., 1991), and diagnostic dyspraxia (Tanaka, 1994; Tanaka et al., 1996). Consequently, knowledge about normal ultra-structure of rats' corpus callosum is crucial for comparing the data with the diseased ones (Shenton et al., 2013).

Different approaches were used to entitle the gender differences in adult rats' $\mathrm{CC}$. Regional studies suggested that the midsagittal area is larger in males than females (Berrebi et al., 1988; Fitch et al., 1990; Zimmerberg \& Mickus, 1990; Denenberg et al., 1991; Fitch et al., 1991a; Mack et al., 1993; Dubb et al., 2003); whereas ultra-structural studies on rats revealed no sex difference in the number of myelinated axons or the size of axons (Juraska \& Kopcik, 1988; Mack et al., 1995). Males, on the other hand, seem to have a thicker myelin sheath (Mack et al., 1995).

Since it is complicated to perform ultra-structure examination on human, some magnetic resonance imaging (MRI) studies of human CC have revealed positive sexual differences in its shape and size (Dubb et al.). On the other hand, other MRI studies reported no sexual differences neither in CC size (Weis et al., 1989; Allen et al., 1991; Ardekani et al., 2012) nor in splenial thickness (Gupta et al., 2011). Data obtained from postmortem human brains indicated that small diameter $(<2 \mu \mathrm{m})$, lightly myelinated fibers were abundant in the genu and splenium and connected higher-association areas, whereas large diameter fibers ( $>2$ $\mu \mathrm{m})$ were predominant in the body and isthmus and connected primary motor and somatosensory areas, there were no comparisons between gender (Witelson, 1989; Highley et al., 1999; Hopkins \& Nir, 2010; Hopkins et al., 2012).

Although there is considerable information about neuromorphological sex differences in several neocortical regions and the gross size of the corpus callosum, there is insufficient data about sex differences in the axonal composition, size and diameter of different CC regions. Therefore, the present study aimed to examine the ultrastructural differences of the major sectors between adult male and female rats using transmission electron microscopy
(TEM). Moreover, variation in axonal diameter along with myelin sheath thickness were examined and compared in all sub regions.

\section{MATERIAL AND METHOD}

Animals preparation. This experimental study was performed on 6-8 months old white American rats, 3 rats per cage and bred in (Jordan animal house) closed colony with free access to food and water and 12 hours dark/light cycles.

Principles of laboratory animal care were in accordance with the University of Jordan Home Office Guidance regulations and with the approval of local ethical committee.

A total of 10 rats were used (5 males and 5 females). The rats were anaesthetized by chloroform, perfused with 1 $\%$ paraformaldehyde and $1.25 \%$ glutaraldehyde in sodium phosphate buffer $(\mathrm{pH}=7.3)$. One female rat died before the end of complete perfusion and was excluded due to lack of proper fixation. The brains were then extracted, trimmed and fixed in $3 \%$ glutaraldehyde overnight. The next day, the brains were sectioned using leica vibrating microtome, to obtain slices of $200 \mathrm{~mm}$ thick in different CC regions. By using a dissecting microscope, $\mathrm{CC}$ sub-regions were isolated.

Electron microscopy. The tissues were post fixed with buffered 1-2 \% osmium tetroxide for $1 \mathrm{~h}$, gradually dehydrated in ethanol/propylene oxide, and embedded in an epoxy resin media mixture. Semi thin sections $(1-2 \mu \mathrm{m})$ were cut with a glass knife and stained with $1 \%$ toluidine blue. The sub regions were identified using light microscope and the block face trimmed to approximately 1 square millimeter. Ultra-thin sections (70-90 nm) were cut using U7 ultra-cut, mounted on 200 mesh copper grids, and contrasted with uranyl acetate and lead citrate. Ultra-thin sections were viewed with a Morgagni electron microscope.

Imaging and statistics. Four digital images from each corner of the grid and one from the center, in 4 different squares of each grid which systematically covered the sub-regions were photographed at a magnification of 11000x. The diameter of myelinated axons and myelin sheath thickness were measured. Myelinated axons on the edge covering more than $2 / 3$ of the photographed area were considered. Differences in these parameters between male and female sub regions were compared using Two Way ANOVA- with Bonferroni post hoc. All statistical analysis was done using SPSS (version 20-IBM, Armonk, Ny, USA). Significance level was considered at $\mathrm{P}<0.05$. 


\section{RESULTS}

This TEM study examined the differences in the mean diameter of myelinated axons (Fig. 1) and the mean myelin sheath thickness (Fig. 2) in four sub-regions of the rat $\mathrm{CC}$, and the data were compared between male (M) and female $(\mathrm{F})$.

Splenium: Males had a significantly higher mean diameter than females in the splenium of the $\mathrm{CC}$ ( $\mathrm{F} 0.471, \mathrm{n}=5, \mathrm{M}$ 0.508, n=5, P <0.05, ANOVA test), (Fig. 3). However, the mean thickness of myelinated axons was higher in females than males ( $\mathrm{F} 0.085, \mathrm{n}=5, \mathrm{M} 0.083, \mathrm{n}=5, \mathrm{P}<0.05$, ANOVA test), though it was statistically not significant.

Posterior Trunk: A significant difference existed in the mean diameter and thickness of myelinated axons of the posterior part of trunk between males and females; with female having a higher diameter and thickness ( $\mathrm{F} 0.088, \mathrm{n}=5$,

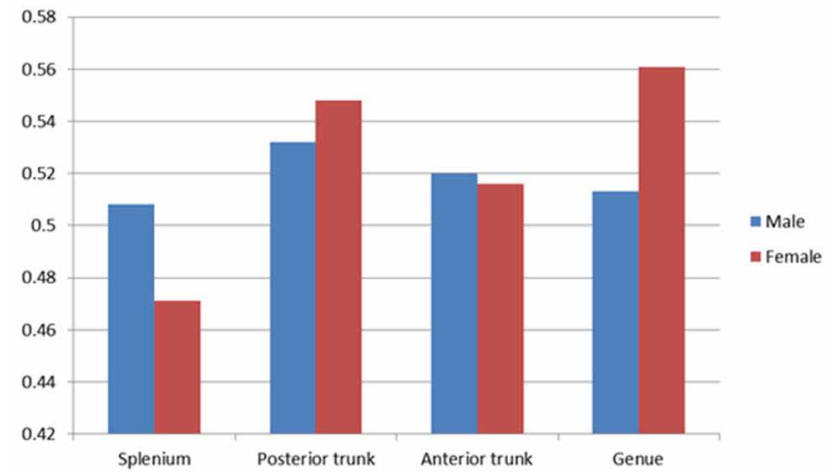

Fig. 1. Relationschip between sex and myelinated axon diameter in adult rat $\mathrm{CC}$.

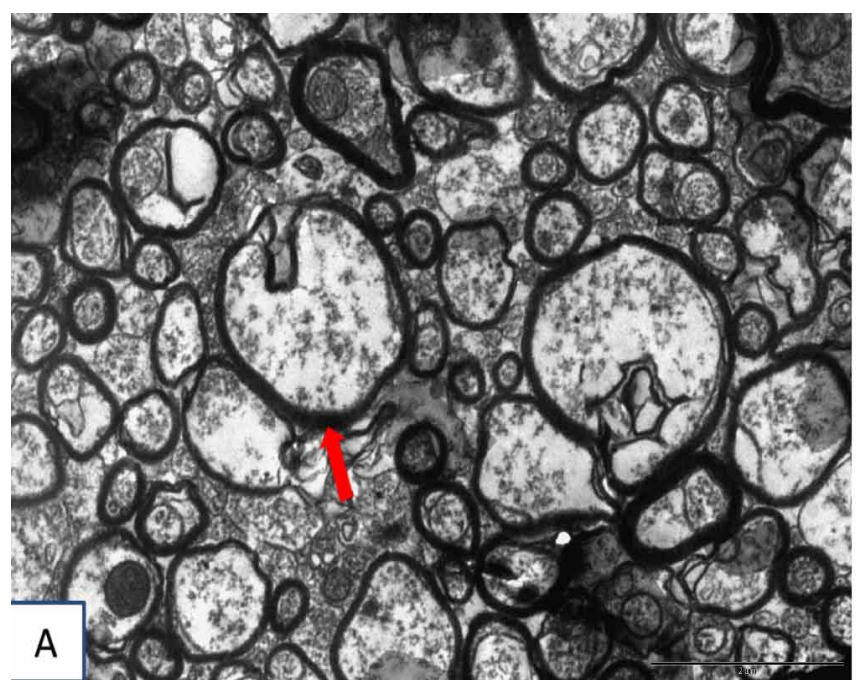

M 0.085, n=5, P <0.05, ANOVA test) and (F 0.548, n=5, M $0.532, \mathrm{n}=5, \mathrm{P}<0.05$, ANOVA test) respectively (Fig. 4).

Anterior trunk: Contrary to the posterior trunk, it was demonstrated that males had a significantly higher mean axonal diameter and thickness than females, (F 0.091, $\mathrm{n}=5$, M 0.094, n=5, P <0.05, ANOVA test) and ( F 0.516, n=5, M $0.520, \mathrm{n}=5, \mathrm{P}<0.05$, ANOVA test) respectively in the anterior trunk of the $\mathrm{CC}$ (Fig. 5).

Genu: Data obtained from the genu of the CC have shown a significant difference between male and female mean axonal diameter and thickness. Female had a higher diameter $(\mathrm{F}$ 0.56, $\mathrm{n}=5, \mathrm{M} 0.513, \mathrm{n}=5, \mathrm{P}<0.05$, ANOVA test), as well as a thicker (F 0.098, n=5, M 0.088, n=5, P <0.05, ANOVA test) myelinated axons than males in the genu of the corpus callosum (Fig. 6).

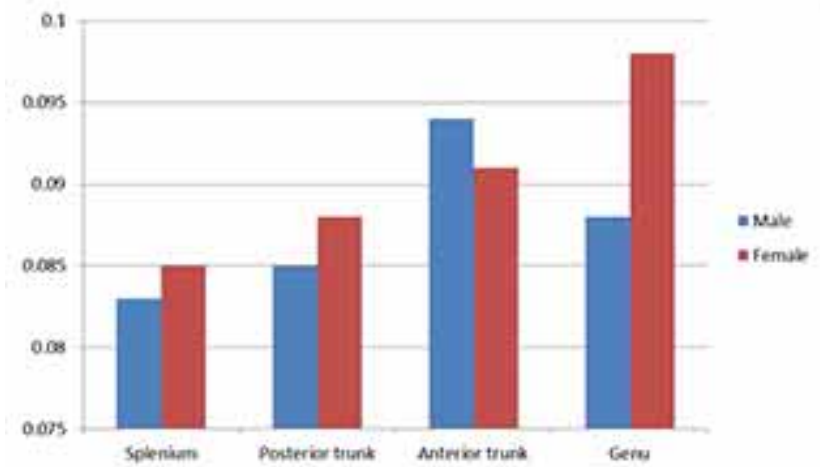

Fig. 2. Relationschip between sex and thisckness of myelin sheath in adult rat CC.

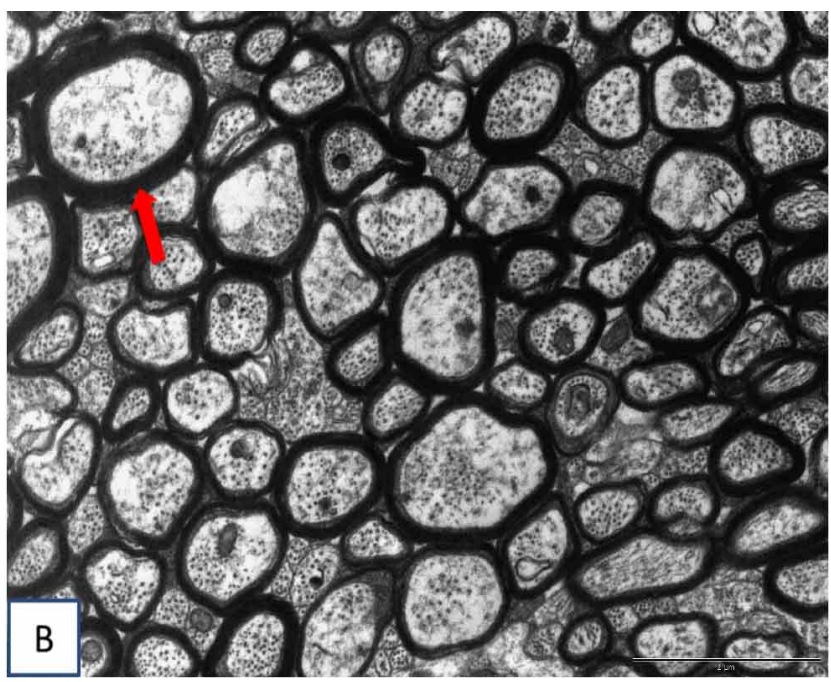

Fig. 3. Electron micrograph of adult A) Male, B) Female Splenium, showing myelinated (arrow) and unmyelinated axons. 

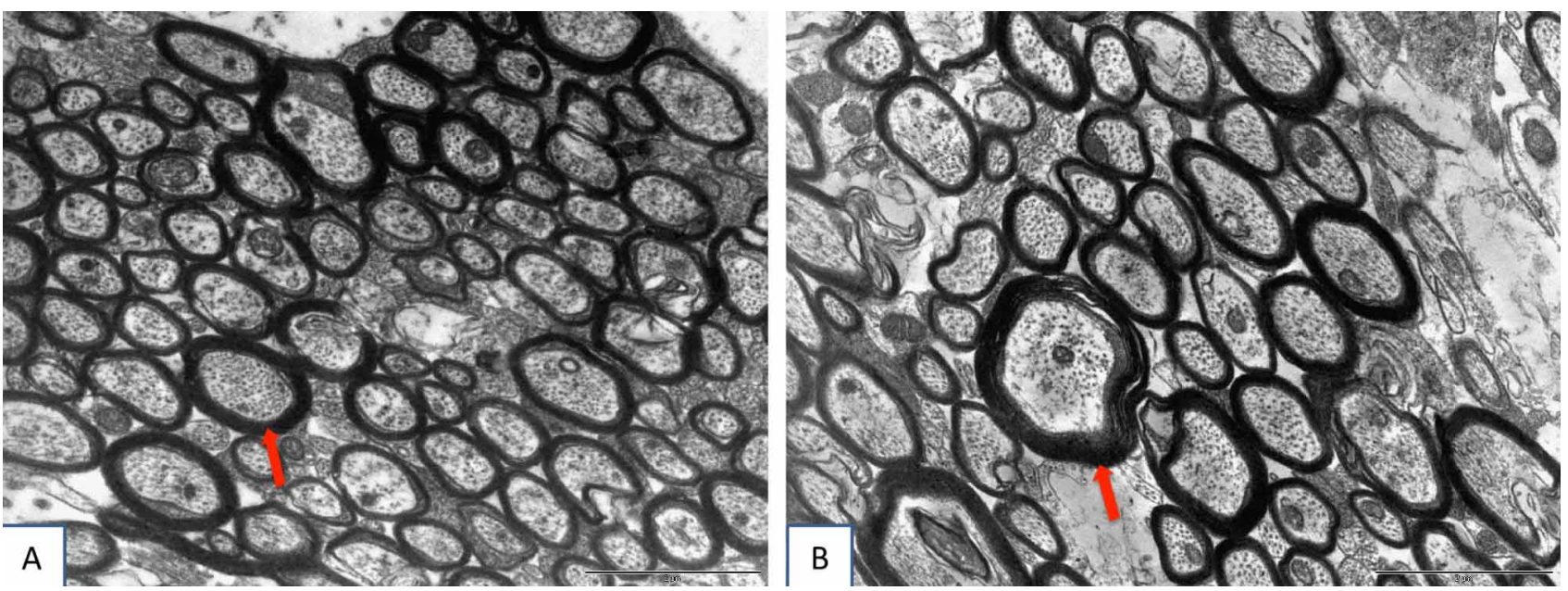

Fig. 4. Electron micrograph of adult A) Male, B) Female posterior trunk, showing myelinated (arrow) and unmyelinated axons.
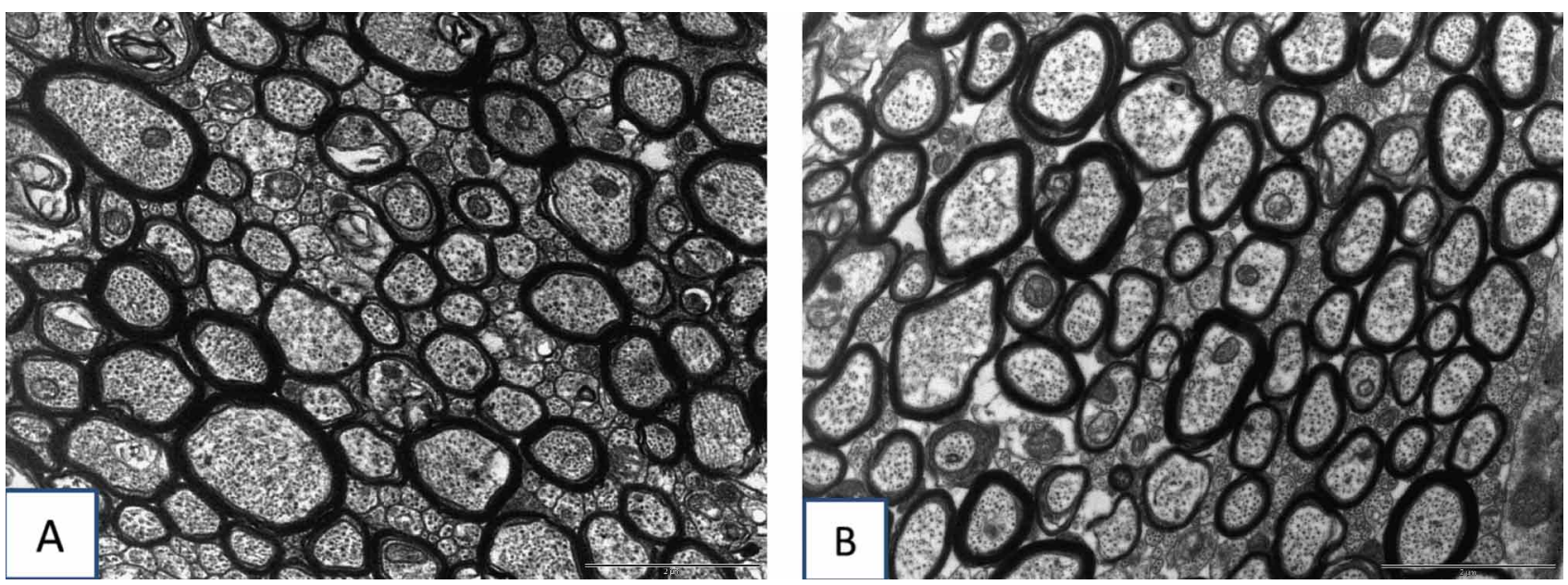

Fig. 5. Electron micrograph of adult A) Male, B) Female anterior trunk, showing myelinated (arrow) and unmyelinated axons.
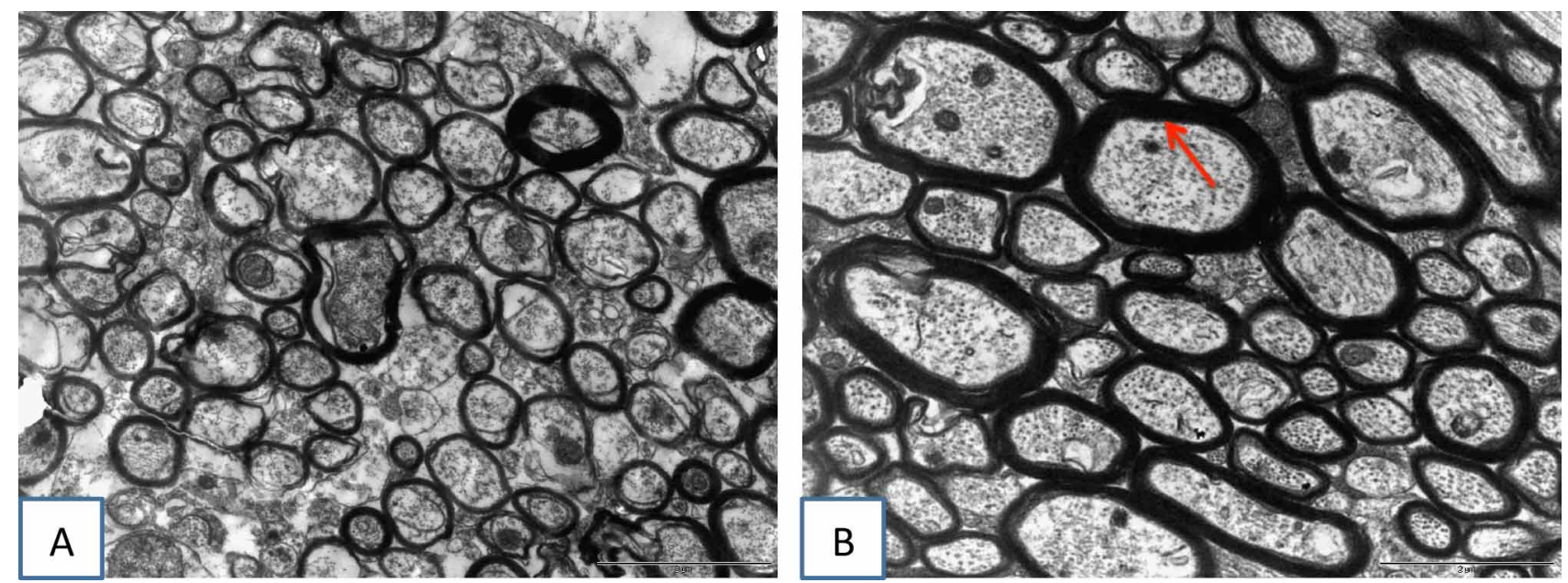

Fig. 6. Electron micrograph of adult A) Male, B) Female genu, showing myelinated (arrow) and unmyelinated axons. 


\section{DISCUSSION}

Herein we report a gender based ultrastructural regional difference in both axons diameter and myelin sheath thickness among different parts of rats CC. Females had the upper hand in axons diameter and myelin sheath thickness in the genu and posterior part of the trunk while males had higher axons diameter and myelin sheath thickness in the splenium and in the anterior part of the of the trunk of CC.

Sex differences have been reported in animal species like birds, dogs, hamsters, and rhesus monkeys (Nottebohm \& Arnold, 1976; Berrebi et al.; Kolb \& Stewart). The influence of gender on the prevalence of some diseases was always questioned, for example, the prevalence of autism in males. Answers to this question were driving scientists to examine hormones, as hormones regulate different activities in our body and they also influence the development of all organs and of course our brain. For instance, it has been shown that many regions of the rat's brain are sexually dimorphic due to the effect of gonadal hormones (Arnold \& Gorski, 1984). Similar to other regions of the neocortex, the $\mathrm{CC}$ is sensitive to the effects of sex hormones (Diamond et al.; Stewart \& Kolb; MuñozCueto et al., 1990; Fitch et al., 1991b; Kolb \& Stewart; Mack et al., 1993, 1996; Nuñez \& Juraska, 1998).

Although some studies have approached the ultrastructure of the $\mathrm{CC}$ but they were not involved in studying sexual dimorphism. For example, an electron microscopic examination of old and young rats for quantifying the ultra-structural pathological changes of the $\mathrm{CC}$ axons was conducted but without addressing sex difference (Sargon et al., 2007). In addition, the morphology, number, and density of myelinated nerve fibers were evaluated but only in the cingulated bundle and genu of the corpus callosum (Bowley et al., 2010). The current study has thoroughly explored each part of the $\mathrm{CC}$ to measure the axons diameter and myelin sheath thickness of the neurons within these parts.

Splenium. The present study has revealed that males have significantly higher myelinated axon diameter than females in the splenium of CC. In line with these results are the findings of Rabi et al. (2007) where males had larger diameter of fibers in the mid-body and splenium of CC. It has also been demonstrated that in adults, the overall volume of white matter is higher in men than in women (Gur et al., 2002). However, an earlier study, has reported that there was no significant sex difference in the average diameter of myelinated axons in rats (Kim, Ellman, \& Juraska, 1996).
The present study did not investigate the possible causes to why males have significantly higher axon diameter than females in the splenium of $\mathrm{CC}$, however, it has been shown that testosterone, particularly, plays an important role in CC dimorphism (Nuñez \& Juraska) and early myelination in central and peripheral nerves (Levy et al., 1996), since females who were given testosterone neonatally had larger splenium than normal females (Allen et al.; Nuñez \& Juraska).

The present study has also demonstrated that the mean thickness of the myelinated axons was higher in females than in males though it was statistically not significant. These results are consistent with the observation that the maximum splenium width and the CC total surface area were significantly greater in females (DeLacoste-Utamsing \& Holloway, 1982; Allen et al.; Davatzikos \& Resnick, 1998). MRI images have also supported our finding where it has been revealed that females possess a greater inter-hemispheric connectivity, which contributes to a greater callosal area and better cognitive performance than males (Allen et al.; Davatzikos $\&$ Resnick).

The fact that the mean thickness of the myelinated axons was higher in females than in males, in our study and in other studies, could be attributed to the neurophysiology of the splenium of CC which is directly connected to the temporal lobes and occipital lobes of the brain. In addition, it has been reported that women have more neuronal connections in these areas than men (Allen et al.), as evidenced by the thicker myelin sheath in female CC. Besides, an association between verbal fluency performance and splenial area was also observed in women (Hines et al., 1992; Davatzikos \& Resnick).

Trunk. The trunk of CC is the largest part among other regions of the $\mathrm{CC}$, therefore, it has been divided into anterior and posterior, to evaluate and not to miss any possible differences between these two parts. The anterior part of the trunk of $\mathrm{CC}$ has shown that male possess a higher diameter and thickness of myelinated axons. However, the posterior part of the trunk of CC, in contrary, has shown that female is the one that has a higher diameter and thickness of myelinated axon. Sex difference in the (whole) trunk of the CC was supported by Alonso-Nanclares et al. (2008), who reported lower synaptic density in women in all cortical layers of the temporal neocortex including that of CC. This may support our finding in the anterior trunk, where male exhibited a higher diameter and thickness of myelinated axons. S.J et al. has also reported that males had larger diameter of fibers in the mid-body and splenium of $\mathrm{CC}$ which may correspond to the anterior part of the trunk (S.J et al., 
2007). Furthermore, a significant alterations in the molecular diffusion and in the size of the $\mathrm{CC}$ with respect to gender and handedness in favor to male in the MRI study has also been found (Westerhausen et al., 2004).

Nevertheless, it should be noted that when corpus callosum was divided into seven sub-areas, using three different orientations, significant differences in favor of females in all cases were reported (Constant \& Ruther, 1996). These results seem to be in line with those find in the present study where a higher diameter and thickness of myelinated axons in the posterior trunk were evident. As far as we know, there is insufficient data explaining the sex difference in different sectors of the trunk region of the rat $\mathrm{CC}$, and our current study has an advantage on addressing the gender differences in this region, nevertheless, further investigations are required to confirm this point.

Genu. Data obtained in this present study have clearly demonstrated that both mean axonal diameter and myelin sheath thickness were higher in females in the genu of CC. These results are in agreement with the fact that the anterior part of the genu of the $\mathrm{CC}$ connects the frontal lobes of the brain and these lobes were proven to be larger in female (Gur et al.). In addition, frontal and parietal regions of the cerebral cortex are more folded or convoluted in women than in men (Phillips, 2004). Contrary to our study, the genu was found to be larger in men (Witelson, 1989; Dubb et al.). These results were explained on the assumption that bi-hemispheric communication of the motor tasks is likely to be mediated through genu of the corpus callosum (Dubb et al.). On the other hand, as reported by Mack et al. (1995), the genu showed no significant sex differences in the size of unmyelinated or myelinated fibers.

\section{CONCLUSION}

Functional and morphological studies have revealed that CC capacity is positively associated with its axon size, density (Duaa et al. 2019), as well as its myelination properties (Chahboune et al., 2009; Markham et al., 2009). Therefore, we have focused in this current study on the neurons diameter and myelination, our data have confirmed sexual dimorphism at the ultrastructural level of all regions of CC. However, our data may have contradicted the conclusions of some other studies. Possible reasons for this prevailing controversy may be due to diverse sampling strategy, small sample size, limited resolution of some imaging technique (Allen et al.), also the presence of regio- nal differences within the corpus callosum; thus, the area on which the sample was taken accounts for the accuracy of the results. Furthermore, gross dimensional measures will elude regional shape variations in the CC. Some investigators have divided the corpus callosum into partitions and compared the area of corresponding partitions between the study groups (Witelson, 1985). The difficulty here is that the selection of the partitioning method is arbitrary and subpartition size differences may escape detection (Dubb et al.). Another possibility which could explain this controversy is that, in the current study, other material such as the amount of non-neuronal material, were not measured, which might also show region-specific sex differences (Mack et al., 1995).

ShATARAT, A.; ALZGHOUL, L.; AL QATTAN, D. \& ELBELTAGY, M. Diferencias sexuales anatómicas y ultraestructurales del diámetro medio y grosor de los axones mielinizados en el cuerpo calloso de ratas adultas. Int. J. Morphol., 38(2):505-512, 2020

RESUMEN: El dimorfismo sexual existe en todos los niveles del sistema nervioso. Estas diferencias de sexo podrían ser la base de las diferencias de comportamiento y función neuropsicológica relacionadas con el sexo, así como las diferencias en la prevalencia de diversos trastornos mentales, como el autismo, los trastornos por déficit de atención y la esquizofrenia. La mielinización, por otro lado, es un proceso celular único que puede tener un impacto dramático en la estructura y fisiología de un axón y su tejido circundante. El cuerpo calloso (CC) es la mayor comisura cerebral, que conecta las cortezas cerebrales de ambos hemisferios, y proporciona la conectividad interhemisférica para la transferencia y el procesamiento de información entre regiones corticales. La variación en las propiedades axonales de CC alterará la conectividad interhemisférica. El CC consiste en axones mielinizados y no mielinizados, células gliales y vasos sanguíneos. Varios estudios funcionales han informado que la función de CC está asociada con la densidad de axones y las propiedades de mielinización. El dimorfismo sexual en el contenido axonal del CC siempre ha sido controvertido; por lo tanto, el objetivo de este estudio fue analizar las diferencias en el diámetro de los axones y el grosor de la vaina de mielina del CC entre ratas macho y hembra. Para este propósito, se perfundieron cinco pares de ratas macho y hembra adultas y se extrajeron y seccionaron las CC. Se tiñeron cuatro secciones de diferentes subregiones del cuerpo calloso que representan el genu, el cuerpo anterior, el cuerpo posterior y el esplenio y se capturaron imágenes de microscopía electrónicas utilizando referencias estereológicas. Posteriormente se calculó el diámetro de los axones y el grosor de la vaina de mielina para cada subregión y se compararon entre machos y hembras. Nuestros hallazgos preliminares del presente estudio indicaron diferencias específicas en el grosor y diámetro del axón mielinizado en el CC entre ratas macho y hembra.

PALABRAS CLAVE: Dimorfismo; Cuerpo calloso (CC); Microscopio electrónico; Axones mielinizados; Diámetro y grosor de la vaina de mielina. 


\section{REFERENCES}

Allen, L. S.; Richey, M. F.; Chai, Y. M. \& Gorski, R. A. Sex differences in the corpus callosum of the living human being. J. Neurosci., 11(4):93342, 1991.

Alonso-Nanclares, L.; Gonzalez-Soriano, J.; Rodriguez, J. R. \& DeFelipe, J. Gender differences in human cortical synaptic density. Proc. Natl. Acad. Sci. U. S. A., 105(38):14615-9, 2008.

Ardekani, B. A.; Figarsky, K. \& Sidtis, J. J. Sexual dimorphism in the human corpus callosum: an MRI study using the OASIS brain database. Cereb. Cortex, 23(10):2514-20, 2012.

Arnold, A. P. \& Gorski, R. A. Gonadal steroid induction of structural sex differences in the central nervous system. Аnпи. Rev. Neurosci., 7:41342, 1984.

Berrebi, A. S.; Fitch, R. H.; Ralphe, D. L.; Denenberg, J. O.; Friedrich JR., V. L. \& Denenberg, V. H. Corpus callosum: region-specific effects of sex, early experience and age. Brain Res., 438(1-2):216-24, 1988.

Bowley, M. P.; Cabral, H.; Rosene, D. L. \& Peters, A. Age changes in myelinated nerve fibers of the cingulate bundle and corpus callosum in the Rhesus monkey. J. Comp. Neurol., 518(15):3046-64, 2010.

Cahill, L. Why sex matters for neuroscience. Nat. Rev. Neurosci., 7(6):477$84,2006$.

Cahill, L.; Uncapher, M.; Kilpatrick, L.; Alkire, M. T. \& Turner, J. Sexrelated hemispheric lateralization of amygdala function in emotionally influenced memory: an fMRI investigation. Learn. Mem., 11(3):2616, 2004.

Chahboune, H.; Mishra, A. M.; DeSalvo, M. N.; Staib, L. H.; Purcaro, M.; Scheinost, D.; Papademetris, X.; Fyson, S. J.; Lorincz, M. L.; Crunelli, $\mathrm{V}$; et al. DTI abnormalities in anterior corpus callosum of rats with spike-wave epilepsy. Neuroimage, 47(2):459-66, 2009.

Constant, D. \& Ruther, H. Sexual dimorphism in the human corpus callosum? A comparison of methodologies. Brain Res., 727(1-2):99106, 1996.

Courchesne, E.; Press, G. A. \& Yeung-Courchesne, R. Parietal lobe abnormalities detected with MR in patients with infantile autism. AJR Am. J. Roentgenol., 160(2):387-93, 1993.

Davatzikos, C. \& Resnick, S. M. Sex differences in anatomic measures of interhemispheric connectivity: correlations with cognition in women but not men. Cereb. Cortex, 8(7):635-40, 1998.

DeLacoste-Utamsing, C. \& Holloway, R. L. Sexual dimorphism in the human corpus callosum. Science, 216(4553):1431-2, 1982.

Denenberg, V. H.; Fitch, R. H.; Schrott, L. M.; Cowell, P. E. \& Waters, N. S. Corpus callosum: interactive effects of infantile handling and testosterone in the rat. Behav. Neurosci., 105(4):562-6, 1991.

Diamond, M. C.; Dowling, G. A. \& Johnson, R. E. Morphologic cerebral cortical asymmetry in male and female rats. Exp. Neurol., 71(2):261-8, 1981.

Dubb, A.; Gur, R.; Avants, B. \& Gee, J. Characterization of sexual dimorphism in the human corpus callosum. Neuroimage, 20(1):512-9, 2003.

Egaas, B.; Courchesne, E. \& Saitoh, O. Reduced size of corpus callosum in autism. Arch. Neurol., 52(8):794-801,1995.

Fitch, R. H.; Berrebi, A. S.; Cowell, P. E.; Schrott, L. M. \& Denenberg, V. H. Corpus callosum: effects of neonatal hormones on sexual dimorphism in the rat. Brain Res., 515(1-2):111-6, 1990.

Fitch, R. H.; Cowell, P. E.; Schrott, L. M. \& Denenberg, V. H. Corpus callosum: demasculinization via perinatal anti-androgen. Int. J. Dev. Neurosci., 9(1):35-8, 1991a.

Fitch, R. H.; Cowell, P. E.; Schrott, L. M. \& Denenberg, V. H. Corpus callosum: ovarian hormones and feminization. Brain Res., 542(2):3137, 1991b.

Griffiths, P. D.; Batty, R.; Connolly, D. A. J. \& Reeves, M. J. Effects of failed commissuration on the septum pellucidum and fornix: implications for fetal imaging. Neuroradiology, 51(5):347-56, 2009.
Gupta, E.; Khan, A. A.; Babu, C. S. R.; Lalwani, R. \& Aneja, S. Sexual dimorphism of splenial thickness of corpus callosum. Curr. Neurobiol., 2(1):63-6, 2011.

Gur, R. C.; Gunning-Dixon, F.; Bilker, W. B. \& Gur, R. E. Sex differences in temporo-limbic and frontal brain volumes of healthy adults. Cereb. Cortex, 12(9):998-1003, 2002.

Highley, J. R.; Esiri, M. M.; McDonald, B.; Cortina-Borja, M.; Herron, B. M. \& Crow, T. J. The size and fibre composition of the corpus callosum with respect to gender and schizophrenia: a post-mortem study. Brain, 122(Pt. 1):99-110, 1999.

Hines, M.; Chiu, L.; McAdams, L. A.; Bentler, P. M. \& Lipcamon, J. Cognition and the corpus callosum: verbal fluency, visuospatial ability, and language lateralization related to midsagittal surface areas of callosal subregions. Behav. Neurosci., 106(1):3-14, 1992.

Hopkins, W. D. \& Nir, T. M. Planum temporale surface area and grey matter asymmetries in chimpanzees (Pan troglodytes): the effect of handedness and comparison with findings in humans. Behav. Brain Res., 208(2):43643, 2010.

Hopkins, W. D.; Pilger, J. F.; Storz, R.; Ambrose, A.; Hof, P. R. \& Sherwood, C. C. Planum temporale asymmetries correlate with corpus callosum axon fiber density in chimpanzees (Pan troglodytes). Behav. Brain Res., 234(2):248-54, 2012.

Hynd, G. W.; Semrud-Clikeman, M.; Lorys, A. R.; Novey, E. S.; Eliopulos, D. \& Lyytinen, H. Corpus callosum morphology in attention deficithyperactivity disorder: morphometric analysis of MRI. J. Learn. Disabil., 24(3):141-6, 1991.

Juraska, J. M. \& Kopcik, J. R. Sex and environmental influences on the size and ultrastructure of the rat corpus callosum. Brain Res., 450(1-2):1-8, 1988.

Kendall, B. E. Dysgenesis of the corpus callosum. Neuroradiology, 25(4):23956, 1983.

Kolb, B. \& Stewart, J. Sex-related differences in dendritic branching of cells in the prefrontal cortex of rats. J. Neuroendocrinol., 3(1):95-9, 1991.

Koss, W. A. \& Frick, K. M. Sex differences in hippocampal function. $J$. Neurosci. Res., 95(1-2):539-62, 2017.

Levy, A.; Garcia Segura, M.; Nevo, Z.; David, Y.; Shahar, A. \& Naftolin, F. Action of steroid hormones on growth and differentiation of CNS and spinal cord organotypic cultures. Cell. Mol. Neurobiol., 16(3):445-50, 1996.

Mack, C. M.; Boehm, G. W.; Berrebi, A. S. \& Denenberg, V. H. Sex differences in the distribution of axon types within the genu of the rat corpus callosum. Brain Res., 697(1-2):152-60, 1995.

Mack, C. M.; Fitch, R. H.; Cowell, P. E.; Schrott, L. M. \& Denenberg, V. H. Ovarian estrogen acts to feminize the female rat's corpus callosum. Brain Res. Dev. Brain Res., 71(1):115-9, 1993.

Mack, C. M.; Fitch, R. H.; Hyde, L. A.; Seaman, A. J.; Bimonte, H. A.; Wei, W. \& Denenberg, V. H. Lack of activational influence of ovarian hormones on the size of the female rat's corpus callosum. Physiol. Behav., 60(2):431-4, 1996

Markham, J. A.; Herting, M. M.; Luszpak, A. E.; Juraska, J. M. \& Greenough, W. T. Myelination of the corpus callosum in male and female rats following complex environment housing during adulthood. Brain Res., 1288:9-17, 2009.

Muñoz-Cueto, J. A.; García-Segura, L. M. \& Ruiz-Marcos, A. Developmental sex differences and effect of ovariectomy on the number of cortical pyramidal cell dendritic spines. Brain Res., 515(1-2):64-8, 1990.

Nottebohm, F. \& Arnold, A. P. Sexual dimorphism in vocal control areas of the songbird brain. Science, 194(4261):211-3, 1976.

Nuñez, J. L. \& Juraska, J. M. The size of the splenium of the rat corpus callosum: influence of hormones, sex ratio, and neonatal cryoanesthesia. Dev. Psychobiol., 33(4):295-303, 1998.

Phillips, M. L. Female Brains Have More Folds. In: Chudler, E. H. (Ed.). Neuroscience for Kids. Website. Seattle, Washington, University of Washington, 2004. Available from: https://faculty.washington.edu/ chudler/femcon.html 
Rabi, S. J.; Madhavi, C.; Antonisamy, B. \& Koshi, R. Quantitative analysis of the human corpus callosum under light microscopy. Eur. J. Anat., 11(2):95-100, 2007.

Raybaud, C. The corpus callosum, the other great forebrain commissures, and the septum pellucidum: anatomy, development, and malformation. Neuroradiology, 52(6):447-77, 2010.

Reid, S. N. \& Juraska, J. M. Sex differences in the gross size of the rat neocortex. J. Comp. Neurol., 321(3):442-7, 1992.

Rossi, A.; Stratta, P.; Gallucci, M.; Passariello, R. \& Casacchia, M. Quantification of corpus callosum and ventricles in schizophrenia with nuclear magnetic resonance imaging: a pilot study. Am. J. Psychiatry, 146(1):99-101, 1989.

Sargon, M. F.; Denk, C. C.; Celik, H. H.; Surucu, H. S. \& Aldur, M. M. Electron microscopic examination of the myelinated axons of corpus callosum in perfused young and old rats. Int. J. Neurosci., 117(7):9991010, 2007.

Shenton, M. E.; Hamoda, H. M.; Schneiderman, J. S.; Bouix, S.; Pasternak, O.; Rathi, Y.; Vu, M. A.; Purohit, M. P.; Helmer, K.M; Koerte, I.; et al. A review of magnetic resonance imaging and diffusion tensor imaging findings in mild traumatic brain injury. Brain Imaging Behav., 6(2):13792, 2013.

Sigmundsson, H.; Whiting, H. T. \& Ingvaldsen, R. P. 'putting your foot in it'! A window into clumsy behaviour. Behav. Brain Res., 102(1-2):12936, 1999.

Stewart, J. \& Kolb, B. The effects of neonatal gonadectomy and prenatal stress on cortical thickness and asymmetry in rats. Behav. Neural Biol., 49(3):344-60, 1988.

Tanaka, Y. Responsible lesion for diagnostic dyspraxia. Rinsho Shinkeigaku, 34(3):274-5, 1994.

Tanaka, Y.; Yoshida, A.; Kawahata, N.; Hashimoto, R. \& Obayashi, T. Diagonistic dyspraxia. Clinical characteristics, responsible lesion and possible underlying mechanism. Brain, 119(Pt. 3):859-73, 1996.

Weis, S.; Weber, G.; Wenger, E. \& Kimbacher, M. The controversy about a sexual dimorphism of the human corpus callosum. Int. J. Neurosci., 47(1-2):169-73, 1989

Westerhausen, R.; Kreuder, F.; Dos Santos Sequeira, S.; Walter, C.; Woerner, W.; Wittling, R. A.; Schweiger, E. \& Wittling, W. Effects of handedness and gender on macro- and microstructure of the corpus callosum and its subregions: a combined high-resolution and diffusion-tensor MRI Study. Brain Res. Cogn. Brain Res., 21(3):418-26, 2004.

Witelson, S. F. Hand and sex differences in the isthmus and genu of the human corpus callosum. A postmortem morphological study. Brain, 112(Pt. 3):799-835, 1989.

Witelson, S. F. The brain connection: the corpus callosum is larger in lefthanders. Science, 229(4714):665-8, 1985.

Zimmerberg, B. \& Mickus, L. A. Sex differences in corpus callosum: influence of prenatal alcohol exposure and maternal undernutrition. Brain Res., 537(1-2):115-22, 1990.
Corresponding author:

Loai ALzghoul

University of Jordan

Department of Physiology

Amman

JORDAN

Email: I.zghoul@ju.edu.jo

Received: 08-08-2019

Accepted: 02-10-2019 